\title{
LEAKAGE CURRENT SUPPRESSION IN TRANSFORMER LESS \\ CASCADED H-BRIDGE MLI WITH MODIFIED CPS-PWM TECHNIQUE FOR PV APPLICATIONS
}

\author{
Priya. $\mathbf{R}^{1}$, Amarabalan. ${ }^{2}$, Shanmugasundaram. $\mathrm{C}^{3}$ \\ ${ }^{I}$ Asstistant Professor, EEE, Manakula Vinayagar Institute of Technology, Puducherry, India \\ ${ }^{2}$ Assistant Professor, EEE, Manakula Vinayagar Institute of Technology, Puducherry, India \\ ${ }^{3}$ Assistant Professor, EEE, Manakula Vinayagar Institute of Technology, Puducherry, India
}

\begin{abstract}
This paper presents about the leakage current suppression technique in transformer less cascaded H-Bridge multilevel inverter using CPS $-P W M$ technique for PV system .transformer less topologies have many advantages in terms of weight size cost and efficiency. If transformer is removed galvanic isolation between the PV unit and grid system is lost, leads to insulation of leakage current depends upon switching sequence generation scheme. Therefore adoption of CPS-PWM technique will reduce the leakage current in considerable level. The simulation and experimental verifications of the system are obtained through single phase five level cascaded $H$-bridge multilevel inverter.
\end{abstract}

Keywords: Cascaded H-bridge MLI, CPS-PWM Technique, Leakage Current, Transformer Less MLI

\section{INTRODUCTION}

Photovoltaic inverters has been attracting more attention within private and public sectors, because of their reliability high efficiency, small size, low price factor. In grid connected PV system, galvanic isolation between grid and PV system obtain through transformer. This reduces the leakage current between PV unit and ground transformer is bulk in size and weight and also very expensive. Research has been concentrated to eliminate transformer in PV system. The elimination step results in appearance of leakage current and makes it to flow through between PV units and the ground. Leakage current leads to increase losses, electromagnetic and radio interference issues need to be eliminated with some reasonable range.

If the number of levels in cascaded H-Bridge MLI increases, leakage current reduces. The cascaded H-Bridge MLI suppressing the leakage current in considerable level compared to conventional level single H-Bridge inverter.PWM techniques are adopted for producing the switching sequence to the switches. APOD, POD, PD are the popular PWM techniques. Alternate phase disposition (APOD) - energy carrier waveform is in out of phase with its neighbor carrier by 180 degree. Phase opposition disposition (POD)-all the carrier waveforms are above the zero references are in phase and are 180 degree out of phase with those below zero. Phase disposition (PD) - all carrier waveforms are in phase.The leakage current suppression for transformer less inverter categorized into three different sections adapting different schemes. They are 1.Modulation schemes 2.Topology improvements 3.Usage of improved filters.

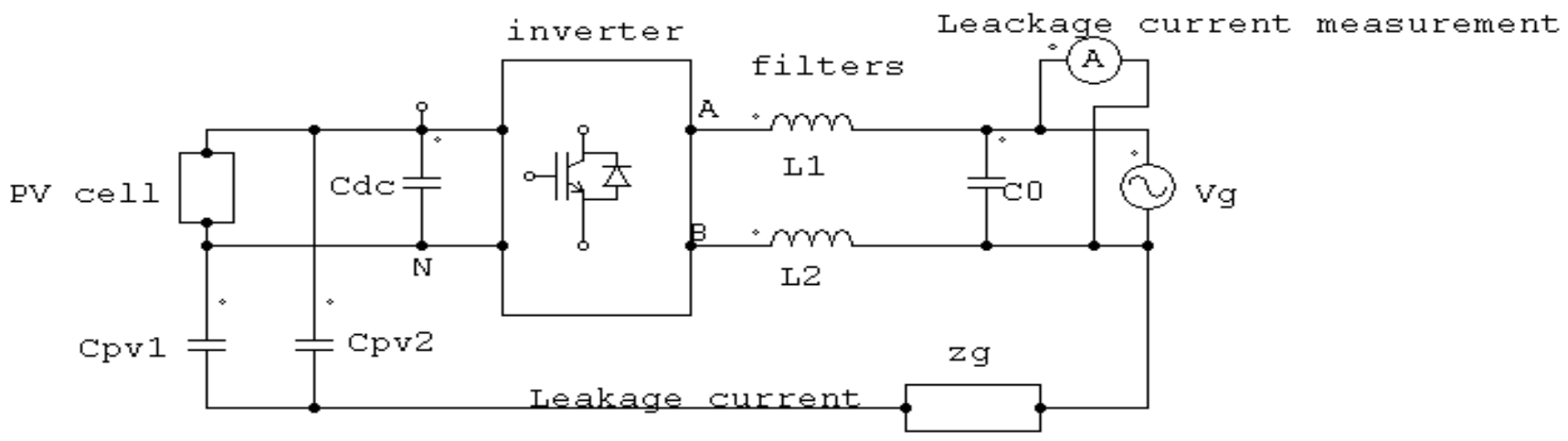

Fig 1. Leakage current flowing through the loop 
Fig 1 depicts that the leakage current is flowing through the loop consisting of $\mathrm{C}_{1}, \mathrm{C}_{2}$, inverter, $\mathrm{L}_{1}, \mathrm{~L}_{2}$, grid and $\mathrm{Z}_{\mathrm{g}}$.

\section{COMMON MODE VOLTAGE}

Common mode voltage is given by the following expression

$\mathrm{V}_{\mathrm{cm}}=\left(\mathrm{V}_{\mathrm{an}}+\mathrm{V}_{\mathrm{bn}}\right) / 2+\left(\mathrm{V}_{\mathrm{an}}-\mathrm{V}_{\mathrm{bn}}\right)\left(\mathrm{L}_{2}-\mathrm{L}_{1}\right) / 2\left(\mathrm{~L}_{1}+\mathrm{L}_{2}\right)$

In order to eliminate the leakage current, common mode voltage must be kept constant. If the no of levels in the cascaded H- Bridge increases ML1 increases, leakage current reduces. The cascaded H-bridge ML1 suppressing the leakage current in considerable level compared to the conventional single $\mathrm{H}$-bridge inverter.PWM techniques are adopted for producing the switching sequence to the switches. APOD, POD, PD are the popular PWM techniques. Alternate phase disposition (APOD) - Energy carrier waveform is in out of phase with its neighbor carrier by 180 degrees. Phase opposition disposition (POD) - All carrier waveforms are above zero references are in phase and are 180 degree out of phase with those below zero. Phase disposition (PD) - All carrier waveforms are in phase.

\section{PROPOSED TRANSFORMER LESS}

\section{TOPOLOGY WITH CPS - PWM TECHNIQUE}

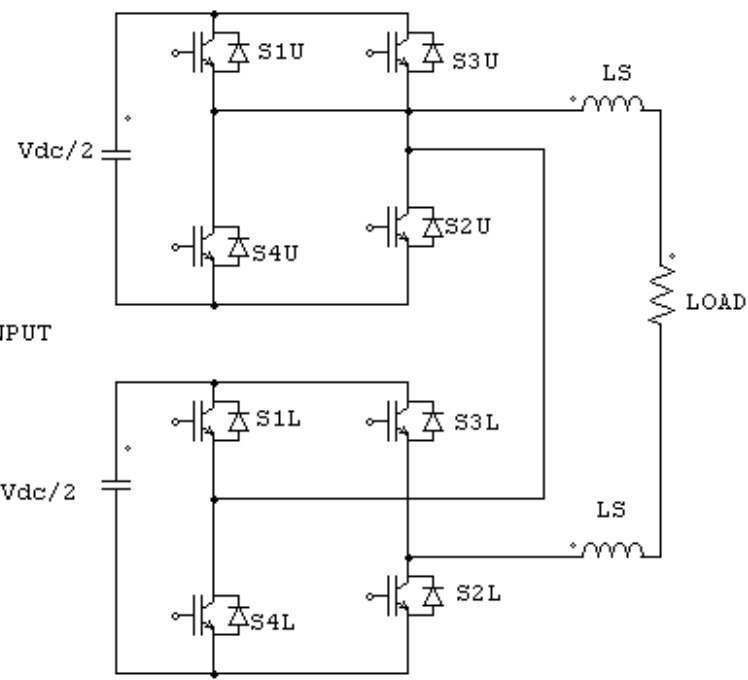

Fig 2. Proposed transformer less MLI topology

Fig (2) shows the single phase five level cascaded H-bridge topology with PV cells as input. Two basic units are connected in series to form multilevel inverter structure. The output voltage levels are $\mathrm{Vdc}, \mathrm{Vdc} / 2,0,-\mathrm{Vdc} / 2$ and Vdc.Leakage current generation depends upon the modulation scheme and topology preferred. Simple R load connection is preferred for the analysis. Leakage current and common mode voltage are measured in the parasitic capacitance. Here, common mode voltage is referred as mean value of voltage between output and common reference point. Negative terminal $(\mathrm{N})$ of DC voltage is referred as common reference point. For upper bridge, lower bridge points $\mathrm{N}$ and $\mathrm{N}^{`}$ are the reference points. The common mode voltage equation is

$\mathrm{V}_{\mathrm{CM}}=\mathrm{V}_{\mathrm{UN}}+\left(\mathrm{V}_{\mathrm{LN}} / 2\right)$

Where,

$\mathrm{V}_{\mathrm{UN}}$ - voltage between midpoint of upper bridge legs to the reference point $\mathrm{N}$.

$\mathrm{V}_{\mathrm{LN}}$ - voltage between the midpoint of lower bridge legs to the reference point $\mathrm{N}^{\text {. }}$.

Leakage current proportional to the VCM value equations are written as,

$\mathrm{V}_{\mathrm{CM}}+\mathrm{V}_{\mathrm{UN}}-\mathrm{V}_{\mathrm{LN}}-\mathrm{V} 0=0$

$\mathrm{V}_{\mathrm{CM}}+\mathrm{V}_{\mathrm{LN}}+\mathrm{V}_{\mathrm{LN}^{-}}-\mathrm{V}_{\mathrm{UL}^{\prime}}=0$

$\mathrm{V}_{\mathrm{L}}$ - Voltage drop across inductance $\mathrm{L}$

$\mathrm{V}_{0}$ - Output voltage across resistive load.

Adding $\mathrm{V}_{\mathrm{L}}$ and $\mathrm{V}_{0}$, we get,

$2 \mathrm{~V}_{\mathrm{CM}}+\mathrm{V}_{\mathrm{UN}}+\mathrm{V}_{\mathrm{LN}}-\mathrm{V}_{\mathrm{UL}^{\prime}}=0$

$\mathrm{V}_{\mathrm{CM}}=\mathrm{V}_{\mathrm{U}^{\prime} \mathrm{L}^{\prime}}-\mathrm{V}_{\mathrm{UN}}-\left(\mathrm{V}_{\mathrm{LN}} / 2\right)$

The value of VCM maybe positive or negative, as already mentioned, leakage current is directly proportional to common voltage, by maintaining considerable minimum value of VCM, leakage current is reduced.

Minimum value of $\mathrm{V}_{\mathrm{CM}}=\mathrm{V}_{\mathrm{dc}} /(\mathrm{n}-1) \quad$ (in MCPWM scheme)

$\mathrm{V}_{\mathrm{CM}}=\mathrm{V}_{\mathrm{dc}} / 2$ (in PDMCPWM scheme)

Here, ' $n$ ' is the number of intervals.

\section{PROPOSED PWM TECHNIQUE}

The proposed modulation scheme is slightly varied up from MC-PWM. Carrier signal requirement is reduced into half the rate. Triangular signals are used as carriers with phase shift of 180 degrees after each half cycle.

Table 1: Switching Instants Vs Common Mode Voltage

\begin{tabular}{|c|c|c|c|c|c|c|c|c|c|c|c|c|}
\hline MODE & $S_{1 U}$ & $\mathbf{S}_{2 \mathrm{U}}$ & $\mathbf{S}_{3 \mathrm{U}}$ & $\mathbf{S}_{4 \mathrm{U}}$ & $S_{1 L}$ & $\mathbf{S}_{2 \mathrm{~L}}$ & $\mathbf{S}_{3 \mathrm{~L}}$ & $S_{4 L}$ & $\mathbf{V}_{\mathrm{UN}}$ & $\mathbf{V}_{\mathrm{LN}}$ & $\mathbf{V}_{\mathrm{UL}}$ & $\mathbf{V}_{\mathrm{CM}}$ \\
\hline \multirow[t]{3}{*}{ o TO T/2 } & 1 & 1 & 0 & 0 & 0 & 0 & 1 & 1 & $\mathrm{~V}_{\mathrm{dc}} / 2$ & 0 & $\mathrm{~V}_{\mathrm{dc}} / 2$ & $\mathrm{~V}_{\mathrm{CM}}$ \\
\hline & 0 & 1 & 0 & 1 & 0 & 0 & 1 & 1 & 0 & 0 & 0 & $2 \mathrm{~V}_{\mathrm{CM} / 4}$ \\
\hline & 0 & 0 & 1 & 1 & 0 & 0 & 1 & 1 & 0 & $\mathrm{~V}_{\mathrm{dc}} / 2$ & $-\mathrm{V}_{\mathrm{dc}} / 2$ & $\mathrm{~V}_{\mathrm{CM} / 4}$ \\
\hline \multirow[t]{3}{*}{$\mathrm{T} / 2 \mathrm{TO} \mathrm{T}$} & 1 & 1 & 0 & 0 & 0 & 0 & 1 & 1 & 0 & $\mathrm{~V}_{\mathrm{dc}} / 2$ & $-\mathrm{V}_{\mathrm{dc}} / 2$ & $2 \mathrm{~V}_{\mathrm{CM} /} / 4$ \\
\hline & 1 & 1 & 0 & 0 & 1 & 0 & 1 & 0 & $\mathrm{~V}_{\mathrm{dc}} / 2$ & $\mathrm{~V}_{\mathrm{dc}} / 2$ & 0 & $\mathrm{~V}_{\mathrm{CM} / 4}$ \\
\hline & 1 & 1 & 0 & 0 & 1 & 1 & 0 & 0 & $\mathrm{~V}_{\mathrm{dc}} / 2$ & 0 & $\mathrm{~V}_{\mathrm{dc}} / 2$ & 0 \\
\hline
\end{tabular}


From the table, it is evident that, one instant has zero, 3 instants has $\mathrm{Vdc} / 4$ and 2 instants has $\mathrm{Vdc} / 4$.

\section{MODE 1: 0 to T/2 duration:}

The two triangular carrier signals are in phase each other three levels. The output voltage levels are $0,-\mathrm{Vdc} / 2$ and Vdc are generated in their model.

\section{Case 1:}

When Vref $<$ Vc1 and Vc2, Switches $S_{1 \mathrm{u}}, \mathrm{S}_{4 \mathrm{u}}, \mathrm{S}_{3 \mathrm{~L}}$ and $\mathrm{S}_{4 \mathrm{~L}}$ are turned $\mathrm{ON}$ and other switches are in turned $\mathrm{OFF}$ position. So the voltage equations are given by,

$\mathrm{V}_{\mathrm{UN}}=\mathrm{Vdc} / 2$

$\mathrm{V}_{\mathrm{LN}}=0$

$\mathrm{V}_{\mathrm{UL}}=\mathrm{Vdc} / 2$

Case 2:

When Vref $>\mathrm{Vc} 2$, Vref $<\mathrm{Vc} 2, \mathrm{~S}_{2 \mathrm{u}}, \mathrm{S}_{4 \mathrm{u}}, \mathrm{S}_{3 \mathrm{~L}}$ and $\mathrm{S}_{4 \mathrm{~L}}$ are turned $\mathrm{ON}$ and other switches are in turned OFF position. So the voltage equations are given by,

So the voltage equations are given by,

$\mathrm{V}_{\mathrm{UN}}=0$

$\mathrm{V}_{\mathrm{LN}}=0$

$\mathrm{V}_{\mathrm{UL}}=0$

Case 3:

When Vref $>$ Vc1, Vc2, Switches $\mathrm{S}_{3 \mathrm{u}}, \mathrm{S}_{4 \mathrm{u}}, \mathrm{S}_{3 \mathrm{~L}}$ and $\mathrm{S}_{4 \mathrm{~L}}$ are turned $\mathrm{ON}$ and other switches are in turned OFF position. So the voltage equations are given by,

$\mathrm{V}_{\mathrm{UN}}=0$

$\mathrm{V}_{\mathrm{LN}}=\mathrm{V}_{\mathrm{dc}} / 2$

$\mathrm{V}_{\mathrm{UL}}=-\mathrm{V}_{\mathrm{dc}} / 2$

\section{MODE 2: T/2 to $T$ duration:}

The two triangular carrier signals are phase shifted by 180 degree. The three output voltage levels are $0,-\mathrm{Vdc} / 2$ and Vdc.

\section{Case 1:}

When $\mathrm{V}_{\text {ref }}<\mathrm{V}_{\mathrm{c1}}, \mathrm{V}_{\mathrm{c} 2}$, switches $\mathrm{S}_{1 \mathrm{u}}, \mathrm{S}_{2 \mathrm{u}}, \mathrm{S}_{3 \mathrm{~L}}$ and $\mathrm{S}_{4 \mathrm{~L}}$ are turned $\mathrm{ON}$ and other switches are turned off. The output voltage equations are given by

$\mathrm{V}_{\mathrm{U}^{\prime} \mathrm{N}^{\prime}}=\mathrm{V}_{\mathrm{dc}} / 2$
$\mathrm{V}_{\mathrm{L}^{\prime} \mathrm{N}^{\prime}}=\mathrm{V}_{\mathrm{dc}} / 2$

$\mathrm{V}_{\mathrm{UL}^{\prime}}=0$

Case 2:

$\mathrm{V}_{\text {ref }}>\mathrm{V}_{\mathrm{c} 1}, \mathrm{~V}_{\text {ref }}<\mathrm{V}_{\mathrm{c} 2}$, Switches $\mathrm{S}_{1 \mathrm{u}}, \mathrm{S}_{2 \mathrm{u}}, \mathrm{S}_{3 \mathrm{~L}}$ and $\mathrm{S}_{1 \mathrm{~L}}$ are turned $\mathrm{ON}$ and other switches are turned off. The output voltage equations are given by

$\mathrm{V}_{\mathrm{UN}^{\prime}}=\mathrm{V}_{\mathrm{dc}} / 2$

$\mathrm{V}_{\mathrm{L}^{\prime} \mathrm{N}^{\prime}}=\mathrm{V}_{\mathrm{dc}} / 2$

$\mathrm{V}_{\mathrm{UL}^{\prime}}=0$

Case 3:

$\mathrm{V}_{\text {ref }}>\mathrm{V}_{\mathrm{cl}}, \mathrm{V}_{\mathrm{c} 2}, \mathrm{~S}_{1 \mathrm{u}}, \mathrm{S}_{2 \mathrm{u}}, \mathrm{S}_{2 \mathrm{~L}}$ and $\mathrm{S}_{4 \mathrm{~L}}$ are turned $\mathrm{ON}$ and other switches are turned off. The output voltage equations are given by

$\mathrm{V}_{\mathrm{U}^{\prime} \mathrm{N}^{\prime}}=\mathrm{V}_{\mathrm{dc}} / 2$

$\mathrm{V}_{\mathrm{L}^{\prime} \mathrm{N}^{\prime}}=0$

$\mathrm{V}_{\mathrm{U}^{\prime}}=\mathrm{V}_{\mathrm{dc}} / 2$

From the above discussions, the common mode voltage band is maintained at the maximum of $\mathrm{Vdc} / 4$.
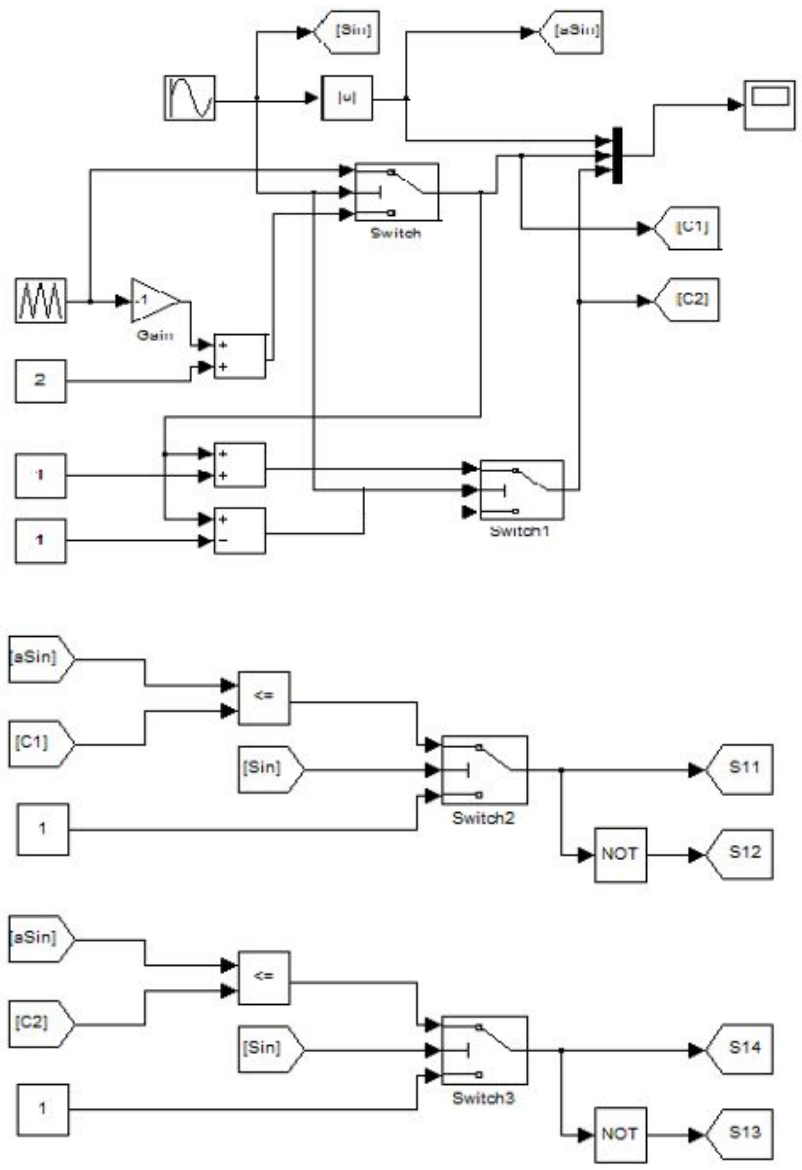

Fig 3. Mat lab simulation files for PWM Generation 


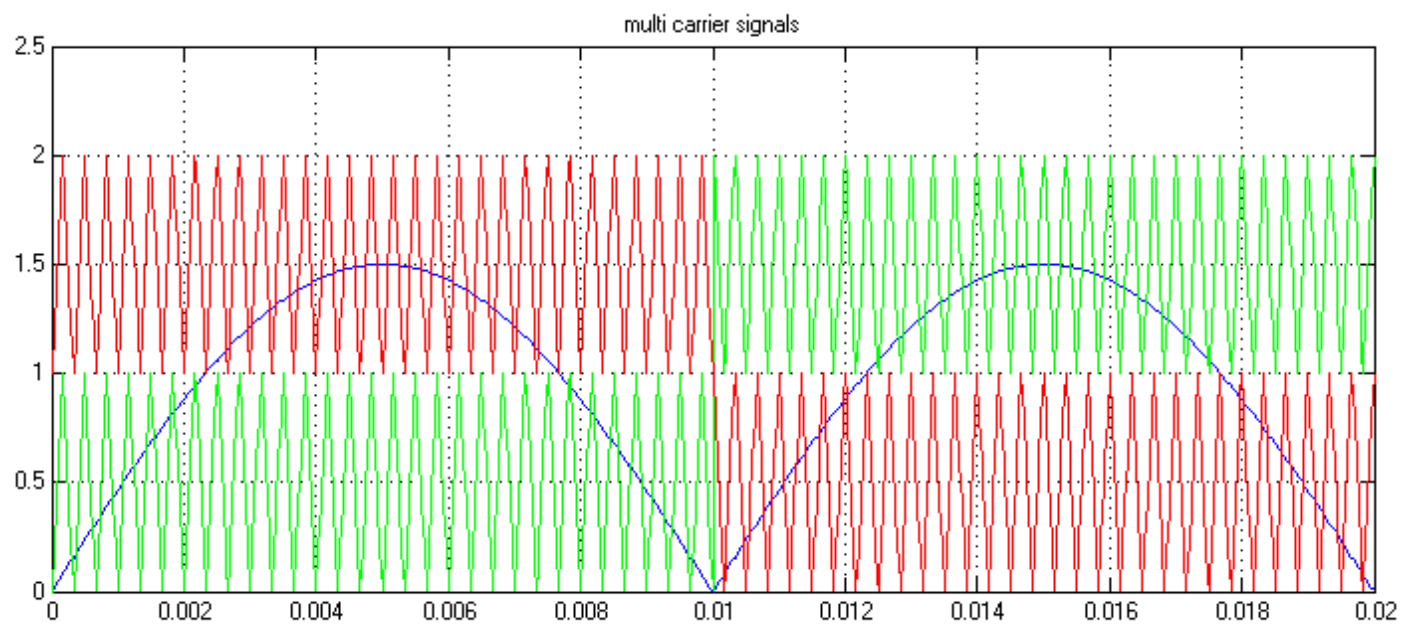

Fig 4.Multi carrier Signals for $\mathrm{PWM}$ generation (Modulated sinusoidal signal with $\mathrm{f}=50 \mathrm{~Hz}$, triangular signal with $\mathrm{f}=1 \mathrm{KHz}$ )
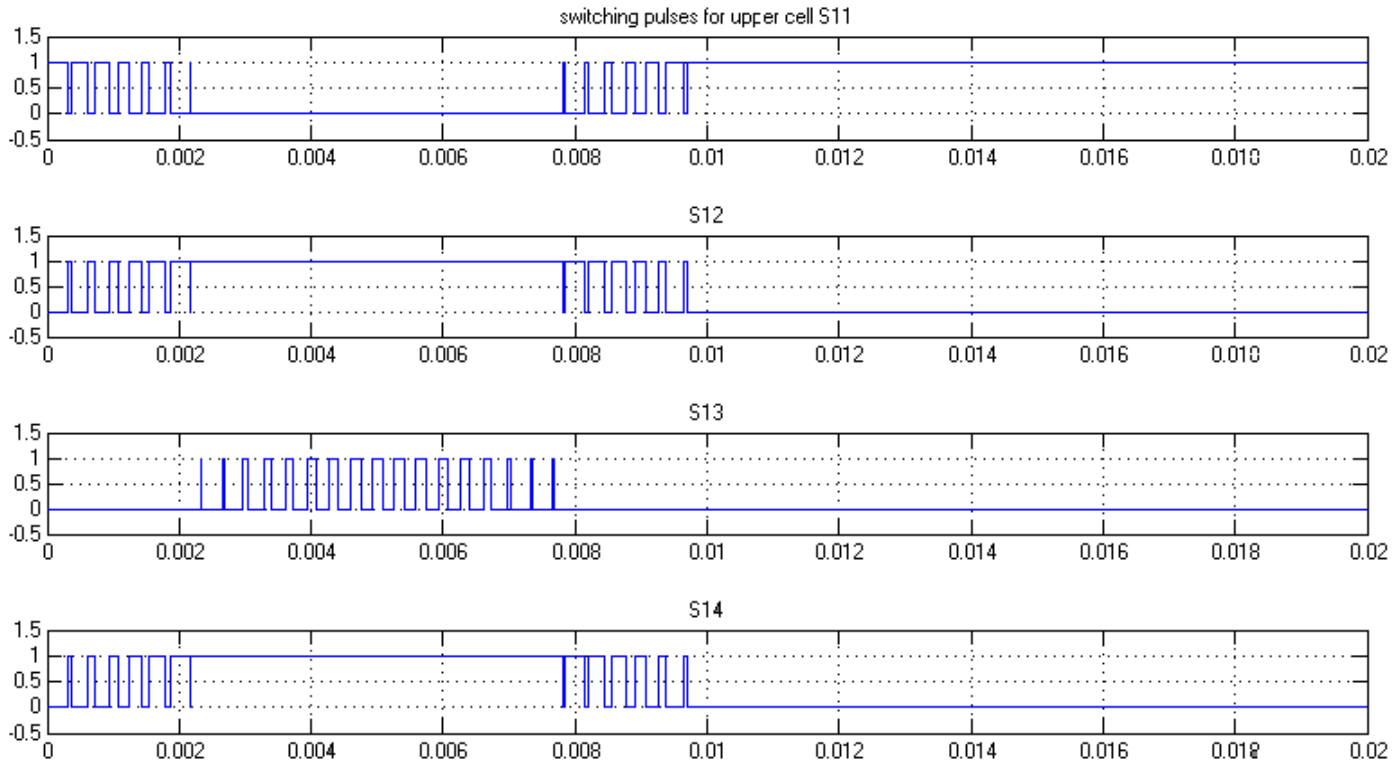

Fig 5: Switching sequence waveforms of upper bridge cells
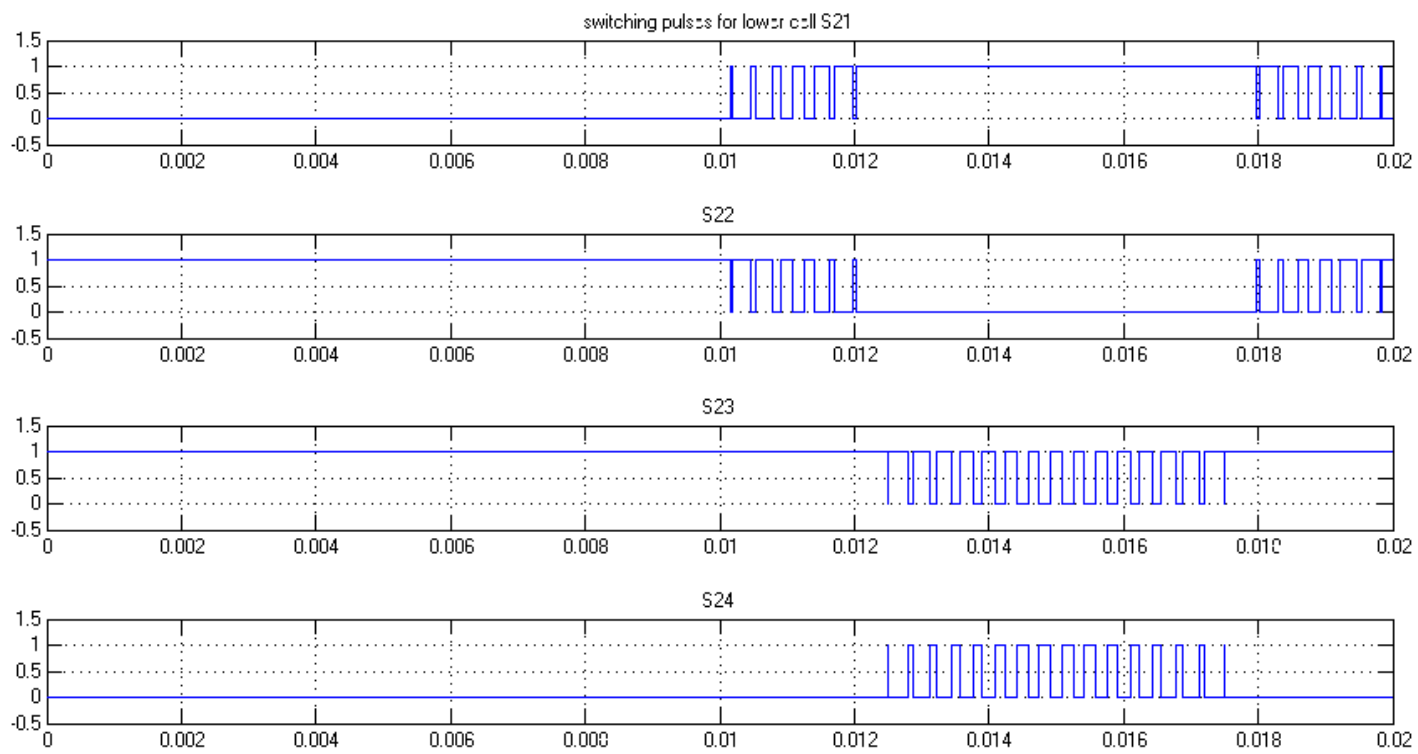

Fig 6: Switching sequence waveforms of lower bridge cells 


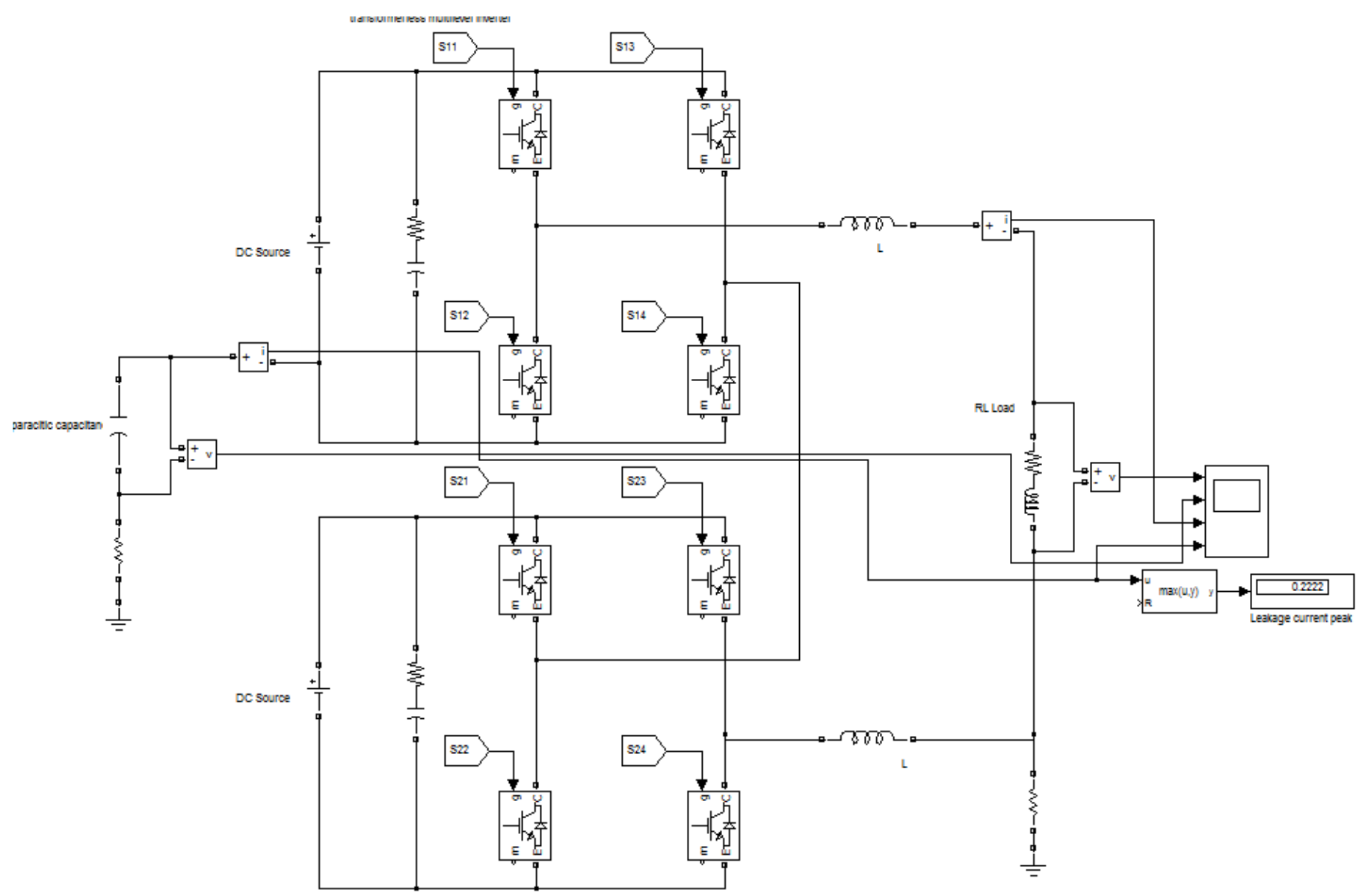

Fig 7: Transformer less multilevel inverter simulation circuit files
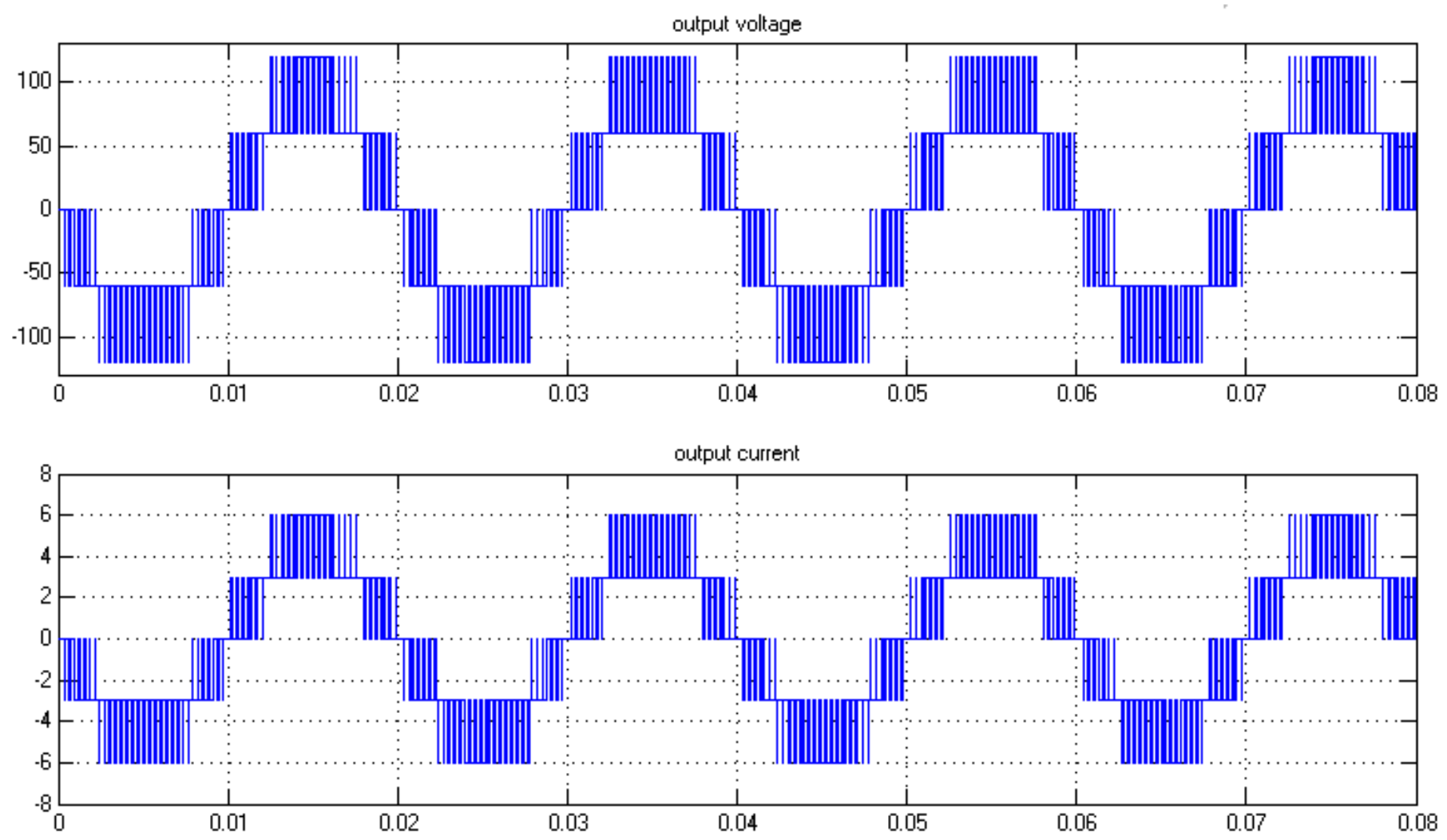

Fig 8.Output voltage and current waveform of transformer less MLI system with R LOAD without output side inductance 

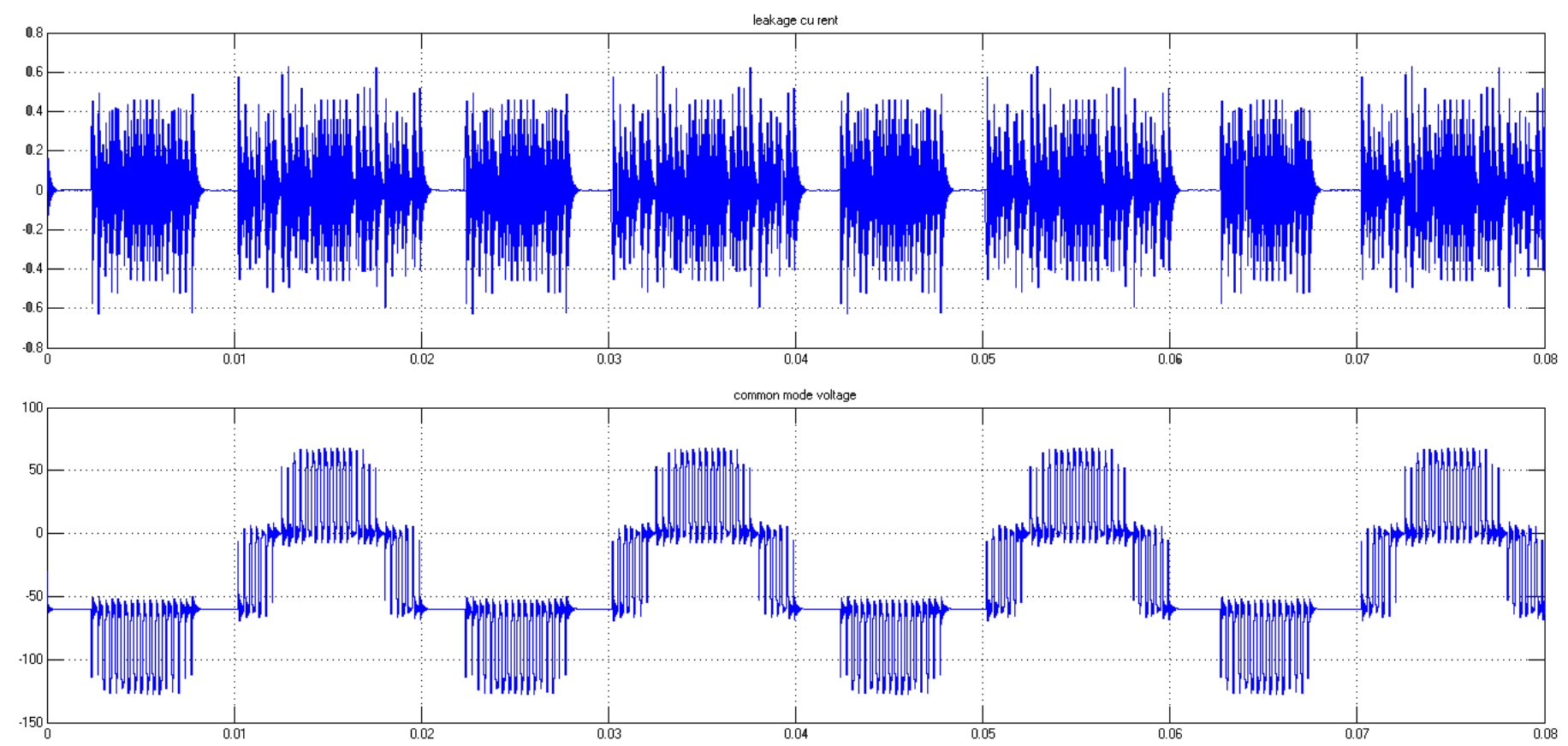

Fig 9.Leakage current and common voltage waveform of transformer less MLI system with R LOAD without output side inductance
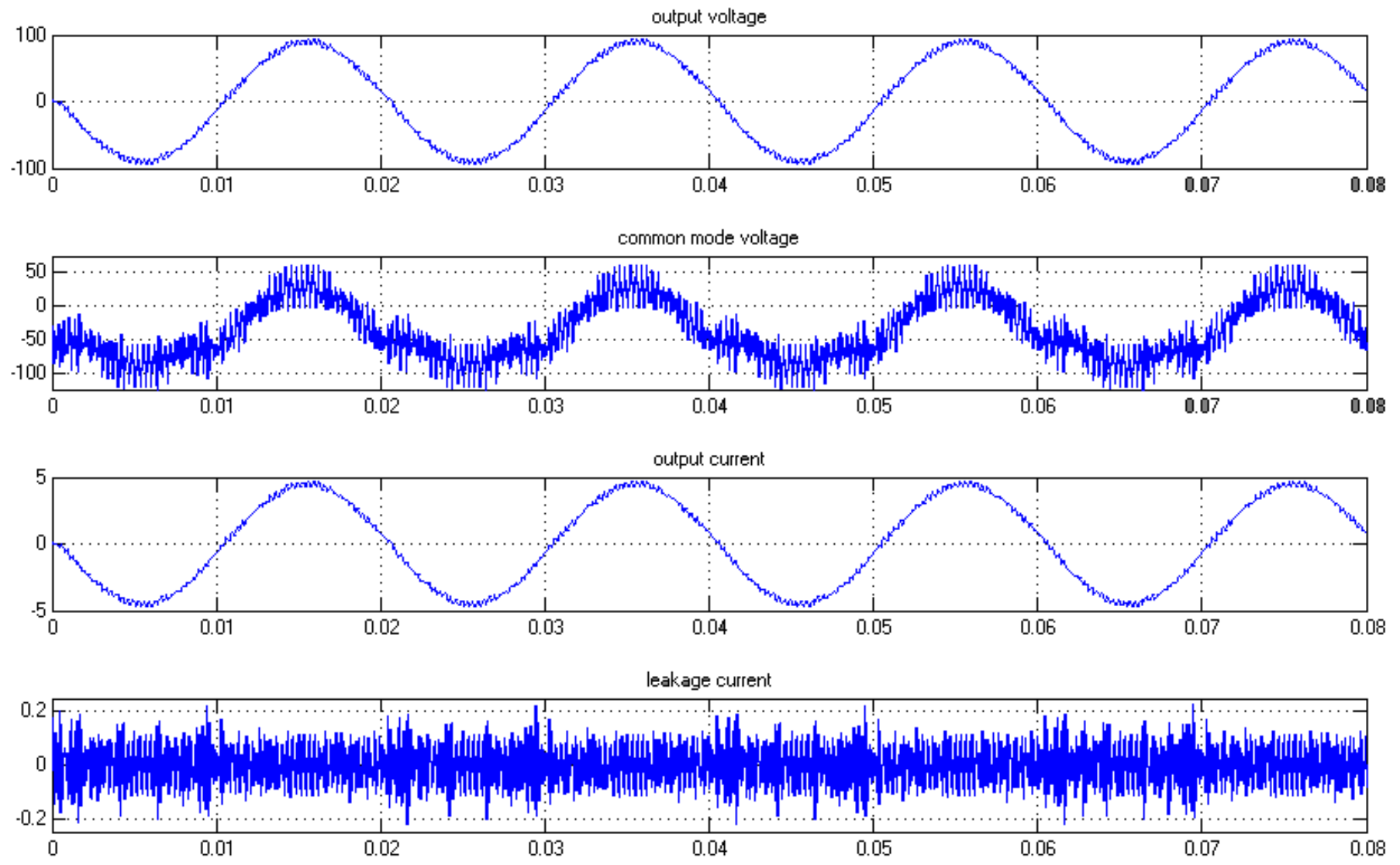

Fig 10:Output voltage, current waveform, Leakage current and common voltage waveform of transformer less MLI system with RL LOAD with output side inductance 

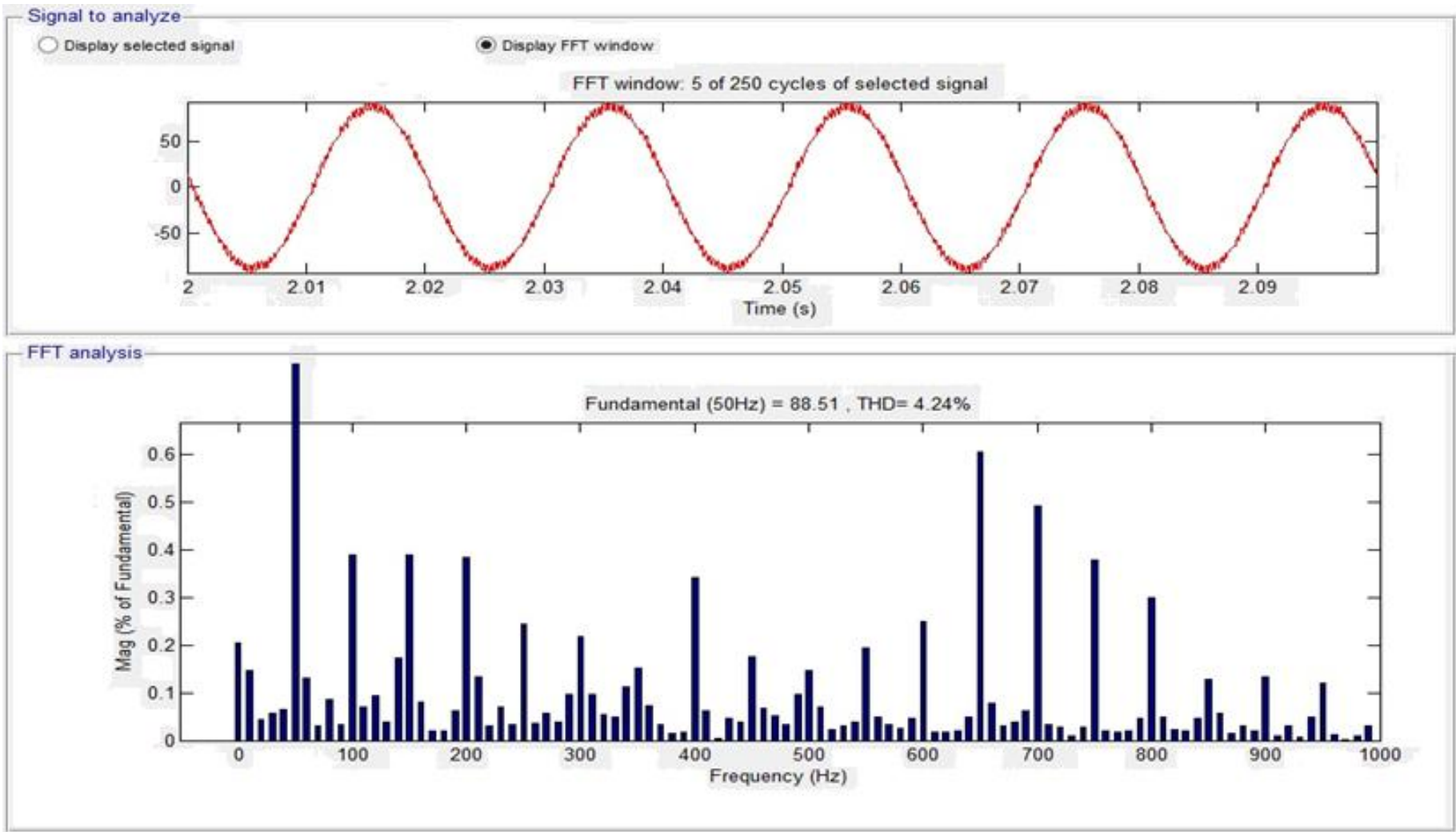

Fig 11: FFT analysis of the multilevel inverter system with proposed MCPWM technique

Table-II. Comparison Table Of Different Modulation Schemes

\begin{tabular}{|l|l|l|l|}
\hline PARAMETER & Phase Disposition & Phase Opposition Disposition & Hybrid \\
\hline THD\% (VOLTAGE) & 31 & 31 & $\mathbf{2 7}$ \\
\hline THD\% (CURRENT) & 4.5 & 5.2 & $\mathbf{4}$ \\
\hline CMV & Very high & High & Low \\
\hline Leakage Current(Peak) & 0.35 & 0.24 & $\mathbf{0 . 2 4}$ \\
\hline Leakage Current(Peak) & 0.09 & 0.08 & $\mathbf{0 . 0 7}$ \\
\hline Carriers Requirement & 4 & 4 & $\mathbf{2}$ \\
\hline
\end{tabular}

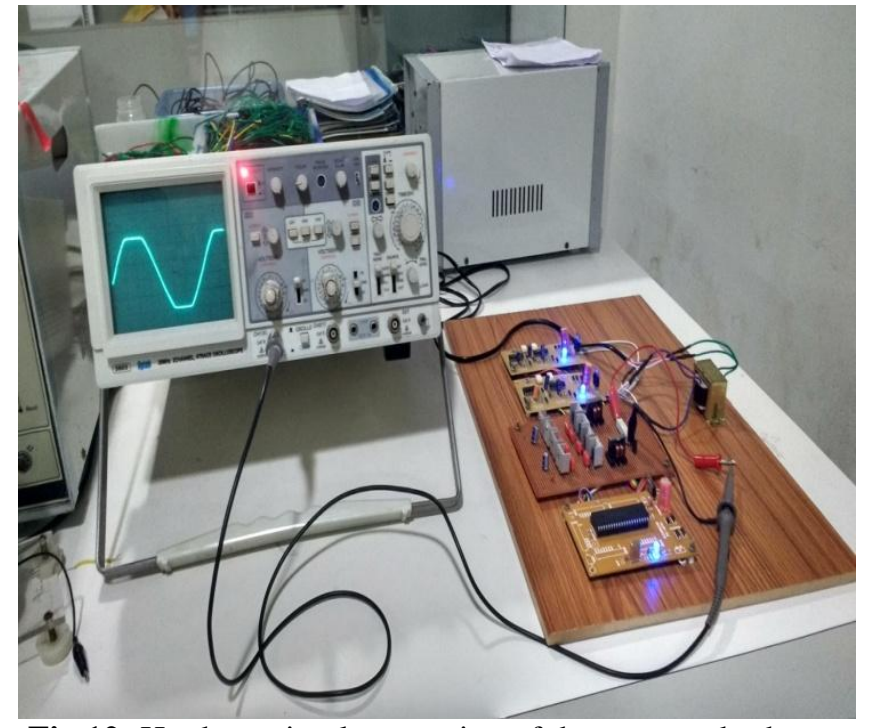

Fig 12: Hardware implementation of the proposed scheme

\section{CONCLUSION}

This paper proposes about the methods adopted for the suppression of leakage current in transformer less multilevel inverter system which is best applicable for PV applications. The removal process of transformer in the conventional system causing the flow of leakage current in the system. The modified PWM technique requires only two triangular carrier signals to produce five level inverter output voltage. The proposed hybrid multicarrier PWM technique results in the reduced common mode voltage and leakage current in considerable amount as compared to the other modulation strategies (PD\&POD) technique. It is also observed that the proposed system reduces the total harmonic distortion in considerable percentage.

\section{REFERENCES}

[1] Xiaoqiang, M.C Cavalcanti, A.M Farias and J.M Guerrero, "Single-Carrier Modulation for Neutral- 
Point-Clamped Inverters in Three-Phase

Transformerless Photovoltaic Systems," IEEE Trans. on Power Electron., vol.28, no.6, pp.2635-2637, June 2013.

[2] E. Koutroulis, and F. Blaabjerg, "Design Optimization of Transformerless Grid-Connected PV Inverters Including Reliability," IEEE Trans. on Power Electron., vol.28, no.1, pp.325-335, Jan. 2013.

[3] Topologies for Transformerless Photovoltaic Grid-Tied Inverters," IEEE Trans. on Power Electron.vol.28, no.2, pp.730-739, Feb. 2013.

[4] Y. Bo, Li. Wuhua, G. Yunjie, C. Wenfeng, H. Xiangning, "Improved Transformerless Inverter With Common-Mode Leakage Current Elimination for a Photovoltaic Grid-Connected Power System," IEEE Trans. on Power Electron., vol.27, no.2, pp.752-762, Feb. 2012.

[5] M. M. Renge, and H. M. Suryawanshi, "Five-level diode clamped inverter to eliminate common mode voltage and reduce $\mathrm{dv} / \mathrm{dt}$ in medium voltage rating induction motor drives," IEEE Trans Power Electron., vol.23, no. 4, pp. 1598-1607, Jul. 2008.

[6] E. Koutroulis, and F. Blaabjerg, "Design Optimization of Transformerless Grid-Connected PV Inverters Including Reliability," IEEE Trans. on Power Electron., vol.28, no.1, pp.325-335, Jan. 2013.

[7] Y. Zhou and H. Li, "Analysis and Suppression of Leakage Current in Cascaded-Multilevel-Inverter based PV systems", IEEE Trans. on Power Electron., vol. 29, no. 10, pp.5265-5277, Oct. 2014.

[8] R. Gonzalez, E. Gubia, J. Lopez, and L. Marroyo, "Transformerless single phase multilevel-based photovoltaic inverter," IEEE Trans. Ind. Electron., vol. 55, no. 7, pp. 2694-2702, Jul. 2008. 